\title{
NOTE ON THE TRANSLATIONS
}

$\prod_{H}$

HE CONTESTANTS SUBMitTing essays to the prize contests of the Bordeaux Royal Academy of Sciences had the choice of writing in either French or Latin, the two scholarly linguae francae of the day. Eleven of the nineteen essays appearing in this volume (eight from the 1741 contest, three from that of 1772) were written in French; the other eight were composed in Latin.

To translate the submissions from this pan-European contest into English, the editors worked with a team of four translators. Karen C. C. Dalton, director and curator of the Image of the Black Archive and Library (a project of the Hutchins Center for African and African American Research), and Susan Emanuel, a veteran professional translator of numerous works of French scholarship into English, undertook the translations of the French essays. Translations of the Latin submissions were provided by Sheldon Cheek, also with the Image of the Black Archive and Library, and Rosanna Giammanco, the principal at Verbum Linguistic Services and translator of more than thirty books from Latin and Italian into English. Additionally, Ben Lee, professor at Oberlin College, provided valuable consultation at an early stage of the Latin translations.

Reading and transcribing the often idiosyncratic script of the essays posed one of the greatest challenges to the translators. Several essays are written on both sides of relatively translucent paper, producing a vexing double image. There were also occasional lapses in the text produced by illegible 
characters as well as fragments hidden within the gutters of the bound volumes.

Our goal was to produce a version of the essays in readily accessible, modern English. Thematic titles and headnotes have been added to the essays in the interest of clarity. Some of the essays have been redacted. Much of the rambling and repetitive arguments made in Essay 6, for example, required significant abridgment. Such edits are noted within the text by an ellipsis between brackets: [...]. The texts of more cogently argued essays, on the other hand, have been retained in their entirety.

The last sentence of each of the translated essays from the 1741 contest reflects a stratagem designed by the Bordeaux Academy to maintain the anonymity of the essay contestants. Each author was told to append a relevant aphorism to his submission. At the close of the contest, these edifying sayings were to be matched with a list of authors' names kept secret from the jury. Some essayists chose passages from the Old Testament of the Bible. Two of these directly relate to the subject of the contest. The author of Essay 12, for example, quotes a phrase from the beginning of the Song of Songs, one of the most eloquent books found in Holy Scripture: "I am black, but beautiful." Equally apropos is the selection from Proverbs chosen by the author of Essay 7: "Can the Ethiopian change his skin?"

After the assessment of the essays by the jurors, Jean Barbot, secretary of the Royal Academy, recorded the status of each essay. All of them were deemed unworthy of a prize, or had arrived too late to be considered by the jury. Their rejection by the academy is succinctly stated in the upper lefthand corner of the first page of each essay: "read, examined, and rejected from the competition" or received "outside the time of the contest." The essay sent in by Eric Molin numbers among these late arrivals. Docketed "at Amsterdam, 15 February, 1742," it was received well after the contest had ended. The reasons for this are found in the manuscript of his essay. He reveals that he had not seen the original announcement of the contest in the Journal des savants. Rather, he had learned about the competition more informally through some "scholarly gentlemen of Amsterdam."

This small anecdotal detail, revealed within Molin's candid though unsolicited biographical sketch, suggests the broad character of the ongoing Enlightenment debate over what it meant to be human. In addition to taking shape in the era's scientific journals, the idea of what would soon come to be known as "race" was the product of an expansive European conversation occurring in prestigious national academies, anatomy theaters, royal palaces, as well as in the more informal environment of the public café. 